\title{
Photosensitizer effect of curcumin on UVB-irradiated HaCaT cells through activation of caspase pathways
}

\author{
KUN PARK ${ }^{1}$ and JI-HYE LEE ${ }^{2}$ \\ Departments of ${ }^{1}$ Dermatology and ${ }^{2}$ Internal Medicine, College of Medicine Eulji University, Seoul, Korea
}

Received September 8, 2006; Accepted November 27, 2006

\begin{abstract}
Photodynamic therapy (PDT) using photosensitizer can induce diverse cellular responses, including apoptosis. Recently, it has been reported that PDT using methylaminolaevulinate may be effective in basal cell carcinoma. However, it is largely unknown whether PDT using a natural product such as curcumin can induce apoptosis in skin cancer. In this study, to confirm the photodynamic effect of curcumin, we investigated the synergistic effect of the combination of UVB with curcumin on apoptotic cell death in HaCaT cells and molecular mechanisms underlying apoptosis. Our data showed that HaCaT cells were markedly undergoing apoptosis, evidenced by DNA laddering, by combination of UVB with curcumin, compared to UVB or curcumin alone. Furthermore, combination of UVB irradiation with curcumin synergistically induces apoptotic cell death in $\mathrm{HaCaT}$ cells through activation of caspase- 8 , and -3 as well as caspase- 9 activation followed by release of cytochrome c. Thus, our data indicate that curcumin may be a promising photosensitizer used in PDT to induce apoptosis in skin cancer cells.
\end{abstract}

\section{Introduction}

Photodynamic therapy (PDT) using photosensitizer can induce diverse cellular responses, including apoptosis $(1,2)$. PDT is becoming an established treatment for selected neoplastic lesions, especially in skin cancer (3-5). PDT using methylaminolaevulinate may be effective in basal cell carcinoma $(6,7)$. However, it is largely unknown whether PDT using natural product such as curcumin can induce apoptosis in skin cancer.

Curcumin is the major constituent of turmeric powder, extracted from the rhizomes of the plant Curcuma longa. Curcumin has been described as having antioxidant, antiinflammatory, and anti-carcinogenic properties (8-11). However, the anti-carcinogenic mechanisms of curcumin

Correspondence to: Dr Kun Park, Department of Dermatology, Eulji Hospital, 280-1, Hagye 1-dong, Nowon-gu, Seoul 139-711, Korea

E-mail:derma@chol.com

Key words: photosensitizer, curcumin, HaCaT cells, caspase action are not fully understood. Curcumin may induce apoptosis of cancer cells through blocking of NF-кB survival pathway, generation of reactive oxygen species (ROS), downregulation of $\mathrm{Bcl}-\mathrm{X}_{\mathrm{L}}$, or activation of caspase-8 pathways (1214). Recent evidence indicates that curcumin initiates apoptosis through inducing growth arrest and the DNA damage-inducible gene 153 (GADD153), implying curcumin causes DNA damage through topoisomerase II inhibition (15). Expression of GADD153 is up-regulated when cells are exposed to DNA damaging agent including ultraviolet (UV) irradiation. In addition, Dazard et al reported that DNArepair related genes such as GADD45A and GADD45B are markedly up-regulated in UVB-irradiated human keratinocytes (16). Thus, it is important to investigate whether the combination of UVB and curcumin induces synergistically apoptotic cell death in HaCaT keratinocytes through excessive DNA damage, consequently resulting in activation of caspase pathways. In this study, to confirm the photodynamic effect of curcumin, we investigated the synergistic effect of UVB and curcumin on apoptotic cell death in HaCaT cells and molecular mechanisms underlying apoptosis.

\section{Materials and methods}

Materials. Antibodies against tubulin, PARP, caspase- $3,-8,-9$, and cytochrome c were obtained from Santa Cruz Biotechnology (Santa Cruz, CA). Curcumin was purchased from Sigma-Aldrich (St. Louis, MO).

Cell culture. Human keratinocyte cell line, HaCaT cells, were maintained at $37^{\circ} \mathrm{C}$ in a humidified atmosphere of $95 \%$ air and $5 \% \mathrm{CO}_{2}$ in Eagle's minimum essential medium supplemented with $10 \%$ heat-inactivated fetal bovine serum (FBS), $2 \mathrm{mM}$ glutamine, and $100 \mathrm{U} / \mathrm{ml}$ penicillin and $100 \mu \mathrm{g} / \mathrm{ml}$ streptomycin. For experiments, cells $\left(5 \times 10^{4}\right.$ cells $\left./ \mathrm{ml}\right)$ were seeded in a culture dish, and maintained in the tissue culture incubator. Cells were preincubated with curcumin for $20 \mathrm{~min}$ prior to UVB irradiation at $100 \mathrm{~mJ} / \mathrm{cm}^{2}$.

UVB irradiation. UVB was supplied by a closely spaced array of seven Westinghouse FS-40 sunlamps, which delivered uniform irradiation at a distance of $38 \mathrm{~cm}$. The energy output of UVB (290-320 nm) at $38 \mathrm{~cm}$ was measured with a UVB photometer (IL1350 photometer, International Light, Newburyport, MA). Cells were exposed for 0 and $360 \mathrm{sec}$ of $\mathrm{UVB}$, corresponding to doses of 0 and $400 \mathrm{~mJ} / \mathrm{cm}^{2}$. To prevent 
A.

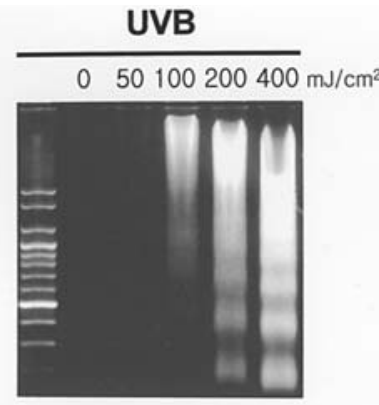

B.

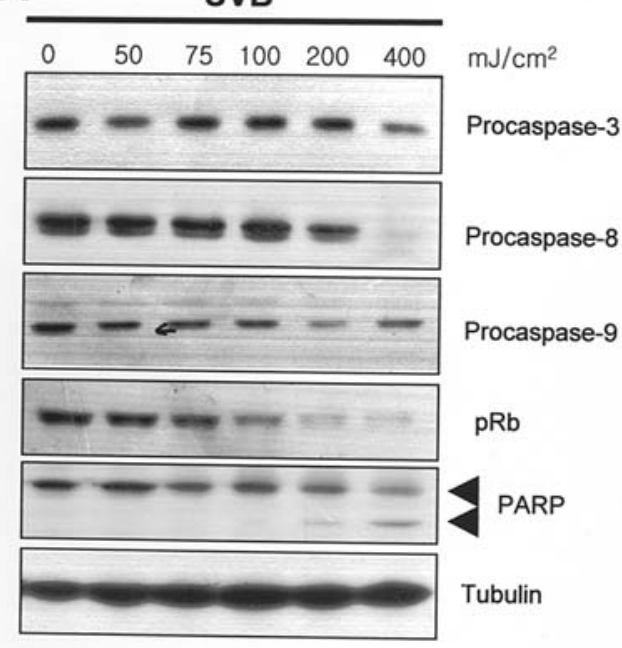

Figure 1. Induction of apoptosis in UVB-irradiated HaCaT cells. Cells were treated by various doses of UVB using seven Westinghouse FS-40 sunlamps. DNA was extracted $24 \mathrm{~h}$ after UVB irradiation and analyzed on a $2 \%$ agarose gel (A). Proteins were also obtained and subjected to Western blot analysis (B). Experiments were repeated two times and similar results were obtained.

light absorption by tissue-culture medium, the culture medium was removed just prior to irradiation and replaced with a thin layer of phosphate-buffered saline (PBS) to cover the cells. After UVB irradiation, cells were fed with fresh growth medium.

Western blot analysis. Cells were lysed in lysis buffer [10 mM Tris (pH 7.4), 5 mM EDTA, $130 \mathrm{mM} \mathrm{NaCl}, 1 \%$ Triton $\mathrm{X}-100$, PMSF $(10 \mu \mathrm{g} / \mathrm{ml})$, aprotinin $(10 \mu \mathrm{g} / \mathrm{ml})$, leupeptin $(10 \mu \mathrm{g} /$ $\mathrm{ml}), 5 \mathrm{mM}$ phenanthroline, and $28 \mathrm{mM}$ benzamidine- $\mathrm{HCl}]$ for $30 \mathrm{~min}$ on ice. Lysates were clarified by centrifugation. Lysates were quantitated using the Bradford assay (Life Science Co., CA, USA) with bovine serum albumin as a reference standard. Proteins $(35 \mu \mathrm{g} / \mathrm{ml})$ were resolved by SDS-PAGE (sodium dodecyl sulfate-polyacrylamide gels) and transferred to immobilon-P transfer membrane (Millipore Co., MA, USA). After incubation with primary antibodies, proteins were visualized by incubation with horseradish peroxidaseconjugated secondary antibodies, followed by ECL according to the manufacturer's instructions (Amersham Life Science Co., Buckinghamshire, UK).

DNA fragmentation assay. Cells were harvested at the indicated times by centrifugation and lysed in ice for $20 \mathrm{~min}$

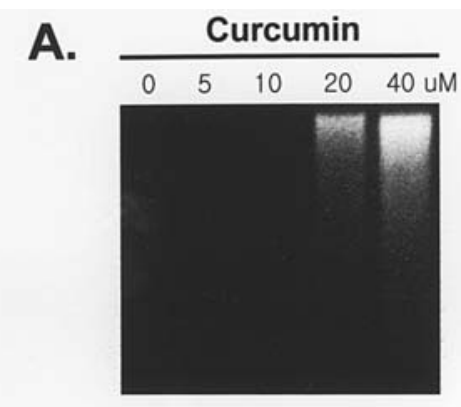

B.

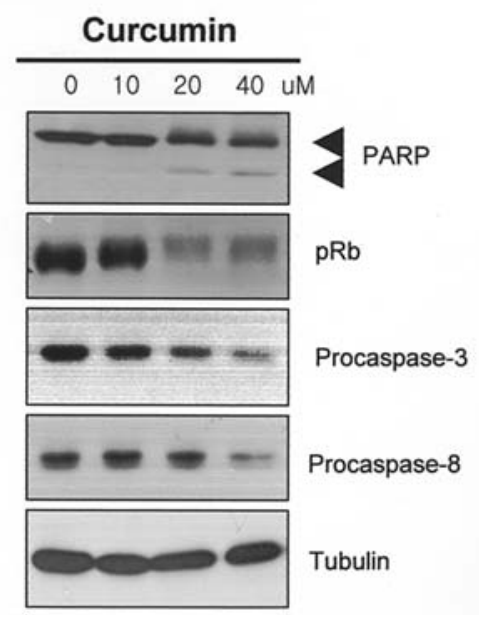

Figure 2. Induction of apoptosis in curcumin-treated HaCaT cells. Cells were treated by various concentrations of curcumin. DNA was extracted $24 \mathrm{~h}$ after curcumin treatment and analyzed on a $2 \%$ agarose gel (A). Proteins were also obtained and subjected to Western blot analysis (B).

by the addition of $20 \mu 1$ lysis buffer consisting of $20 \mathrm{mM}$ EDTA, $100 \mathrm{mM}$ Tris (pH 8.0), and $0.8 \%$ (w/v) sodium lauryl sarcosine. RNase A $(2 \mu 1,5 \mathrm{mg} / \mathrm{ml})$ and proteinase $\mathrm{K}(20 \mu 1$, $10 \mathrm{mg} / \mu \mathrm{l}$ ) were added and incubated at $37^{\circ} \mathrm{C}$ for $1 \mathrm{~h}$ and $2 \mathrm{~h}$, respectively. Total lysates were loaded onto $1.5 \%$ agarose gel and separated at $50 \mathrm{mV}$ for $2 \mathrm{~h}$. DNA fragments were visualized after staining with ethidium bromide by translumination with UV light.

\section{Results}

UVB induces apoptosis in HaCaT cells. To study the effective doses of UVB inducing apoptosis, HaCaT cells were exposed to UVB at doses ranging from 50 to $200 \mathrm{~mJ} / \mathrm{cm}^{2}$, and then cells were harvested $24 \mathrm{~h}$ after irradiation for Western blot and DNA laddering assay. As shown in Fig. 1A, distinct apoptotic DNA ladders were observed at $>100 \mathrm{~mJ} / \mathrm{cm}^{2}$ of UVB. PARP and $\mathrm{pRb}$ cleavages were clearly observed at $>200 \mathrm{~mJ} / \mathrm{cm}^{2}$ doses of UVB, concomitantly with caspase-3, -8, and -9 activation (Fig. 1B).

Curcumin enhances UVB-induced apoptosis in HaCaT cells. To study the effective doses of curcumin inducing apoptosis, $\mathrm{HaCaT}$ cells were treated with various concentrations of curcumin $(5-40 \mu \mathrm{M})$, and then cells were harvested $24 \mathrm{~h}$ after curcumin treatment for DNA laddering and Western blot assay. As shown in Fig. 2A, distinct apoptotic DNA ladders 


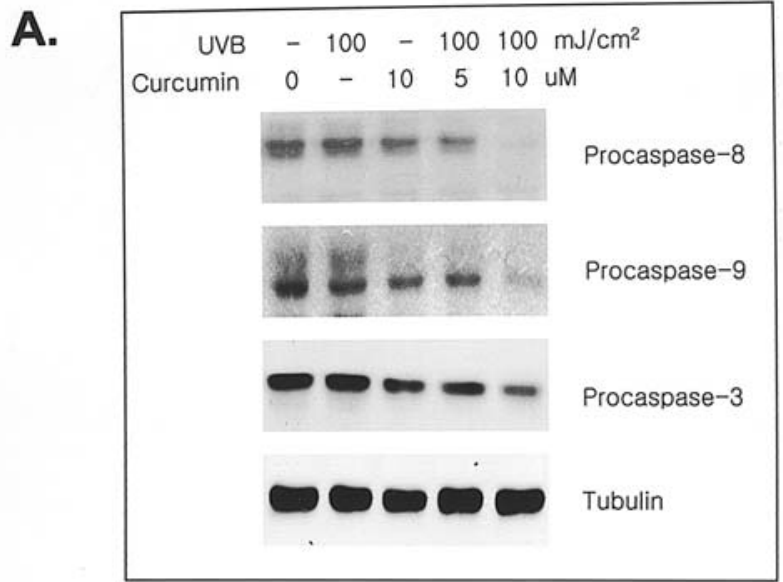

B.
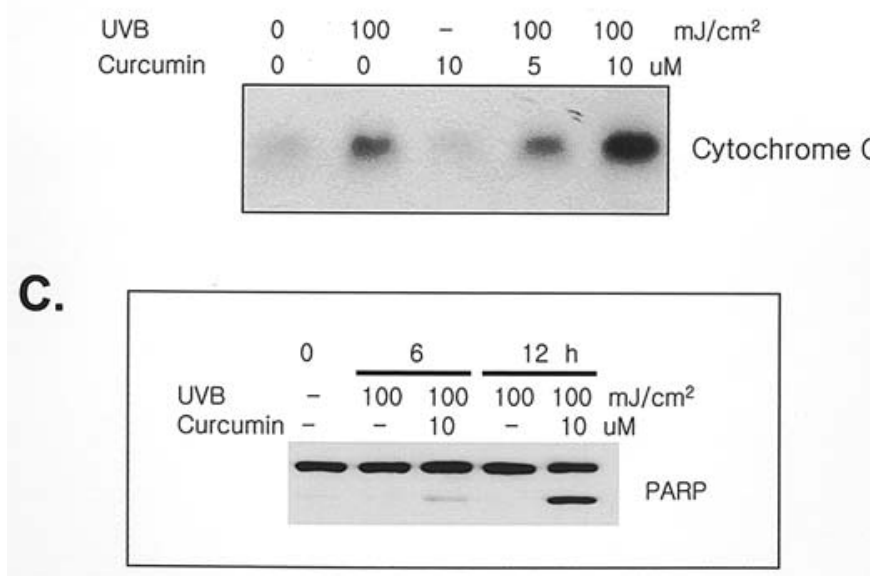

Figure 3. Effect of pretreatment of curcumin on UVB-induced apoptosis. Cells were preincubated with 5 or $10 \mu \mathrm{M}$ curcumin for $20 \mathrm{~min}$ and then exposed to UVB $\left(100 \mathrm{~mJ} / \mathrm{cm}^{2}\right)$. Total proteins and cytosolic fractions were extracted and subjected to immunoblotting using anti-caspases antibodies (A) and cytochrome c antibody (B), respectively. Cells were also preincubated with $10 \mu \mathrm{M}$ curcumin for $20 \mathrm{~min}$ and then exposed to UVB $\left(100 \mathrm{~mJ} / \mathrm{cm}^{2}\right)$. Proteins were extracted at the indicated times and subjected to immunoblotting using anti-PARP antibody. The data are representative of two independent experiments.

were observed at $>20 \mu \mathrm{M}$ of curcumin. PARP and $\mathrm{pRb}$ cleavages were clearly observed at $>20 \mu \mathrm{M}$ concentration of curcumin, concomitantly with caspase- 3 and -8 activation (Fig. 2B).

To study the photodynamic effect of curcumin, HaCaT cells were exposed to sub-apoptotic doses of UVB $(100 \mathrm{~mJ} /$ $\mathrm{cm}^{2}$ ) and cultured in the cultured media including subapoptotic concentration of curcumin (5-10 $\mu \mathrm{M})$, and then cells were harvested $24 \mathrm{~h}$ after irradiation for Western blotting. Activation of caspase-3, -8 , and -9 were clearly observed in combination of UVB with curcumin, but not in UVB or curcumin alone (Fig. 3A). Furthermore, we observed that the level of cytosolic cytochrome $\mathrm{c}$ was higher in UVB with curcumin-treated HaCaT cells than UVB or curcumintreated cells (Fig. 3B). In agreement with caspase-3 activation and cytochrome c level, PARP cleavages were visualized at $6 \mathrm{~h}$ in co-treatment of UVB and curcumin, but not in UVB alone (Fig. 3C).
A.

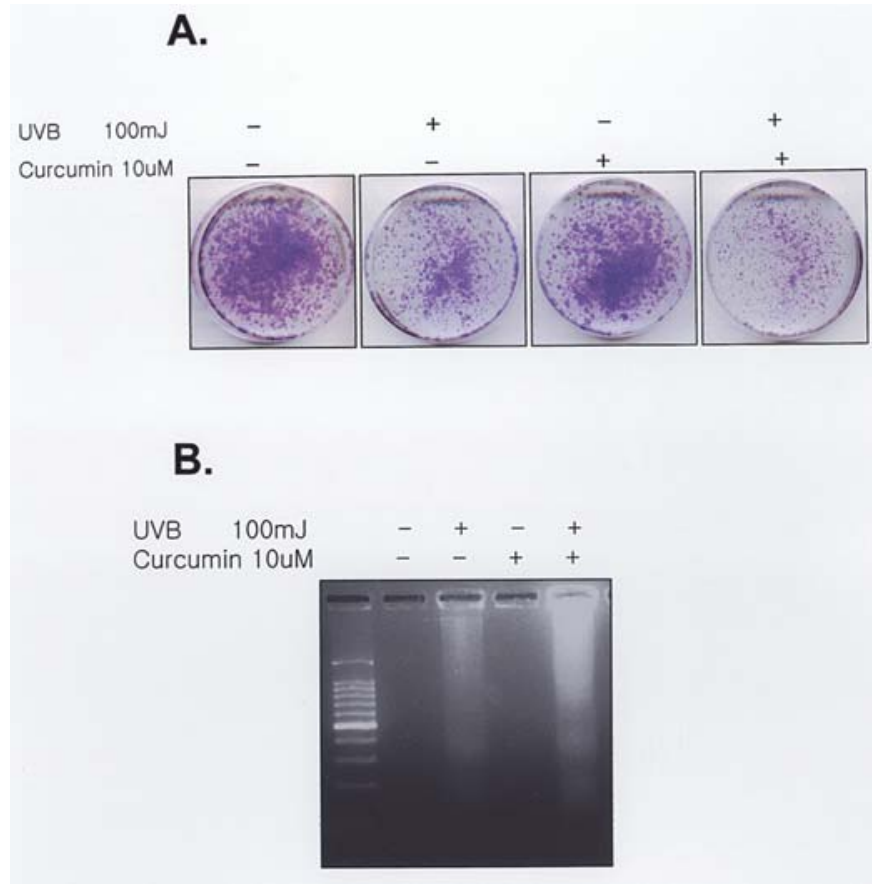

Figure 4. Survival cell colonies and DNA fragmentation assay in combination of curcumin with UVB irradiation. Cells were preincubated with curcumin $(10 \mu \mathrm{M})$ for $20 \mathrm{~min}$ and then exposed to UVB $\left(100 \mathrm{~mJ} / \mathrm{cm}^{2}\right)$. After treatment, cells were cultured for 3 days and then survival colonies were stained using crystal violet staining solution (A). DNA was also extracted $24 \mathrm{~h}$ after curcumin and UVB treatment and analyzed on a $2 \%$ agarose gel (B).

To determine the synergistic effect of co-treatment of UVB with curcumin on inducing apoptosis, we performed survival colony staining in $\mathrm{HaCaT}$ cells 3 days after UVB irradiation with curcumin treatment. Fig. 4A shows that the number of survival colonies was markedly lower in UVB with curcumin-treated HaCaT cells, compared to UVB or curcumin alone. Consistent with the number of survival colonies, distinct DNA fragments were observed in UVB and curcumin co-treated $\mathrm{HaCaT}$ cells, compared to UVB or curcumin alone (Fig. 4B).

\section{Discussion}

Recently, photodynamic therapy (PDT) has emerged as a promising therapeutic tool for treatment of dermatologic conditions such as in situ squamous cell carcinoma, superficial basal cell carcinoma, and malignant melanoma $(5,6,17,18)$. PDT requires the simultaneous presence of a photosensitizer, which accumulates in target cells, and results in induction of apoptosis or necrosis. In this study, our data showed that curcumin may sensitize cells to apoptosis in UVB-irradiated cells through activation of caspase pathways.

Curcumin is a potent chemopreventive agent inhibiting tumor promotion against skin, oral, intestinal and colon carcinogenesis $(11,19,20)$. Our data showed that curcumin induces apoptosis of HaCaT cells, evidenced by DNA fragmentations, caspase- 3 and -8 activation, in a concentrationdependent manner. At concentrations $>20 \mu \mathrm{M}$, there was significant cell death up to $\sim 40 \mu \mathrm{M}$ concentration. In this study, clear reductions of procaspase- 8 and -3 were observed in 
combination of UVB with sub-apoptotic concentration $(10 \mu \mathrm{M})$ of curcumin in $\mathrm{HaCaT}$ cells, compared to UVB or curcumin alone, suggesting that apoptosis is effectively induced by cotreatment of UVB with curcumin through caspase- 8 and -3 activation. Furthermore, release of cytochrome $\mathrm{c}$ and reduction of procaspase- 9 were more prominent in combination of UVB with sub-apoptotic concentration $(10 \mu \mathrm{M})$ of curcumin, compared to UVB or curcumin alone, suggesting that apoptosis is also mediated by mitochondrial-mediated signal pathways. Consistent with our data, Chendil et al reported that curcumin confers radiosensitizing effect in prostate cancer cell line PC-3 through activation of cytochrome c and caspase-9 (21). Koon et al reported that cytotoxicity of curcumin was enhanced by the irradiation of visible light and blue-filtered light in nasopharyngeal cancer cell lines (22). The possible molecular mechanisms of phototoxicity of curcumin might be that curcumin photogenerates singlet oxygen and reduced forms of molecular oxygen as well as inducing the GADD153 gene $(23,24)$.

Thus, our data suggest that curcumin may be developed as a potential photosensitizer, and a chemotherapeutic agent in clinical application, especially in skin cancer.

\section{Acknowledgements}

This study was supported by 2005 Eulji Research Grant (EJRG 05-018-11E23).

\section{References}

1. Moseley H, Ibbotson S, Woods J, et al: Clinical and research applications of photodynamic therapy in dermatology: experience of the Scottish PDT Centre. Lasers Surg Med 38: 403-416, 2006.

2. Babilas P, Landthaler M and Szeimies RM: Photodynamic therapy in dermatology. Eur J Dermatol 16: 340-348, 2006.

3. Tsukagoshi S: Development of a novel photosensitizer, talaporfin sodium, for the photodynamic therapy (PDT). Gan To Kagaku Ryoho 31: 979-985, 2004.

4. Oseroff A: PDT as a cytotoxic agent and biological response modifier: implications for cancer prevention and treatment in immunosuppressed and immunocompetent patients. J Invest Dermatol 126: 542-544, 2006.

5. Baptista J, Martinez C, Leite L and Cochito M: Our PDT experience in the treatment of non-melanoma skin cancer over the last 7 years. J Eur Acad Dermatol Venereol 20: 693-697, 2006.

6. Babilas P, Karrer S, Sidoroff A, Landthaler M and Szeimies RM: Photodynamic therapy in dermatology - an update. Photodermatol Photoimmunol Photomed 21: 142-149, 2005.
7. Morton CA: The emerging role of 5-ALA-PDT in dermatology: is PDT superior to standard treatments? J Dermatolog Treat 13 (Suppl 1): S25-S29, 2002.

8. Gafner S, Lee SK, Cuendet M, et al: Biologic evaluation of curcumin and structural derivatives in cancer chemoprevention model systems. Phytochemistry 65: 2849-2859, 2004.

9. Lin JK and Lin-Shiau SY: Mechanisms of cancer chemoprevention by curcumin. Proc Natl Sci Counc Repub China B 25: 59-66, 2001.

10. Narayan S: Curcumin, a multi-functional chemopreventive agent, blocks growth of colon cancer cells by targeting betacatenin-mediated transactivation and cell-cell adhesion pathways. J Mol Histol 35: 301-307, 2004.

11. Singh S and Khar A: Biological effects of curcumin and its role in cancer chemoprevention and therapy. Anticancer Agents Med Chem 6: 259-270, 2006.

12. Mukhopadhyay A, Bueso-Ramos C, Chatterjee D, Pantazis P and Aggarwal BB: Curcumin downregulates cell survival mechanisms in human prostate cancer cell lines. Oncogene 20: 7597-7609, 2001

13. Notarbartolo M, Poma P, Perri D, Dusonchet L, Cervello M and D'Alessandro N: Antitumor effects of curcumin, alone or in combination with cisplatin or doxorubicin, on human hepatic cancer cells. Analysis of their possible relationship to changes in NF- $\mathrm{KB}$ activation levels and in IAP gene expression. Cancer Lett 224: 53-65, 2005

14. Shishodia S, Amin HM, Lai R and Aggarwal BB: Curcumin (diferuloylmethane) inhibits constitutive NF-kappaB activation, induces $\mathrm{G} 1 / \mathrm{S}$ arrest, suppresses proliferation, and induces apoptosis in mantle cell lymphoma. Biochem Pharmacol 70: 700-713, 2005.

15. Scott DW and Loo G: Curcumin-induced GADD153 gene upregulation in human colon cancer cells. Carcinogenesis 25: 2155-2164, 2004

16. Dazard JE, Gal H, Amariglio N, Rechavi G, Domany E and Givol D: Genome-wide comparison of human keratinocyte and squamous cell carcinoma responses to UVB irradiation: implications for skin and epithelial cancer. Oncogene 22: 2993-3006, 2003.

17. Fergin P: Photodynamic therapy of dermatoses other than non-melanoma skin cancer. Australas J Dermatol 46 (Suppl): S27, 2005

18. Larko O: Photodynamic therapy. Australas J Dermatol 46 (Suppl): S1-S25, 2005.

19. Sharma RA, Gescher AJ and Steward WP. Curcumin: the story so far. Eur J Cancer 41: 1955-1968, 2005.

20. Campbell FC and Collett GP: Chemopreventive properties of curcumin. Future Oncol 1: 405-414, 2005.

21. Chendil D, Ranga RS, Meigooni D, Sathishkumar S and Ahmed MM: Curcumin confers radiosensitizing effect in prostate cancer cell line PC-3. Oncogene 23: 1599-1607, 2004.

22. Koon H, Leung AW, Yue KK and Mak NK: Photodynamic Effect of curcumin on NPC/CNE2 cells. J Environ Pathol Toxicol Oncol 25: 205-216, 2006.

23. Bruzell EM, Morisbak E and Tonnesen HH: Studies on curcumin and curcuminoids. XXIX. Photoinduced cytotoxicity of curcumin in selected aqueous preparations. Photochem Photobiol Sci 4: 523-530, 2005.

24. Dahl TA, Bilski P, Reszka KJ and Chignell CF: Photocytotoxicity of curcumin. Photochem Photobiol 59: 290-294, 1994. 